\title{
Application of research criteria for dementia in common clinical practice
}

Citation for published version (APA):

Verhey, F. R. J., Ponds, R. W. H. M., Reyersen van Buuren, E. J., Vreeling, F. W., \& Jolles, J. (1990). Application of research criteria for dementia in common clinical practice. Neurobiology of Aging, 11(3), 298-299.

Document status and date:

Published: 01/01/1990

Document Version:

Publisher's PDF, also known as Version of record

\section{Please check the document version of this publication:}

- A submitted manuscript is the version of the article upon submission and before peer-review. There can be important differences between the submitted version and the official published version of record.

People interested in the research are advised to contact the author for the final version of the publication, or visit the DOI to the publisher's website.

- The final author version and the galley proof are versions of the publication after peer review.

- The final published version features the final layout of the paper including the volume, issue and page numbers.

Link to publication

\footnotetext{
General rights rights.

- You may freely distribute the URL identifying the publication in the public portal. please follow below link for the End User Agreement:

www.umlib.nl/taverne-license

Take down policy

If you believe that this document breaches copyright please contact us at:

repository@maastrichtuniversity.nl

providing details and we will investigate your claim.
}

Copyright and moral rights for the publications made accessible in the public portal are retained by the authors and/or other copyright owners and it is a condition of accessing publications that users recognise and abide by the legal requirements associated with these

- Users may download and print one copy of any publication from the public portal for the purpose of private study or research.

- You may not further distribute the material or use it for any profit-making activity or commercial gain

If the publication is distributed under the terms of Article $25 \mathrm{fa}$ of the Dutch Copyright Act, indicated by the "Taverne" license above, 


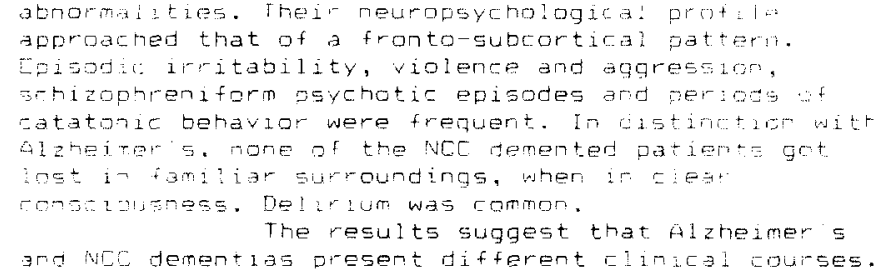

186

PREDICTORS OF INSTITUTIONALIZATION AMONG PATIENTS WITH

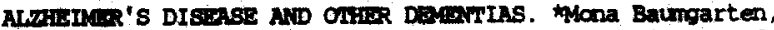
Rubin Becker (st. Justine Comminity Health Department and Mooill University, Montreal, Canada).

The social, psychological, and economic costs associated with institutionalization of the dependent elderly are high. Therefore, a major management goal in the care of patients with Al cheimer's disease or another dementia is to maintain the patient in the cammity for as long as possible. As part of a study on the health of family caregivers (COs) of patients with dementia, our objective was to identify characteristics of patients and $\mathrm{COs}$ which were predictive of institutionalization over a cne year interval. Patients $(n=85)$ with a DSI-III diamosis of dementia were recruited fram the geriatric asseasencent unit of a large Mentreal teaching hospital. All patients were residing in the commity when the study began. Those who were referred to the geriatric unit specifically for pre-placement assessment or for a serious, acute medical problem were exeluded. Data were abtained through hame interviews with the family $O$ and fram the geriatric unit's madical charts. At one-year follow-up, 88 of the patients had died and 348 had been institutionalized; patients who had died were not included in subsequent analyses. When contrasted with patients who were still living in the commity, patients who had been instituticnalized were significantly older and more cognitively impaired, and had a higher level of dependence with respect to activitice of daily living. They were also more likely to be male and had a longer mean duration of dementia, al though these variables were not statistically significant. Patients whose $\infty$ was a child rather thain the spouse had a higher probability of institutionaliration. A higher baseline level of depression among ose was predictive of institutionalization, although the $\infty$ 's physical bealth status (as measured by the number of reported chronic conditions) was not. Although most of the factors predictive of institutionalization are not preventable, knowledge of these factors can help clinicians and cormunity health practitioners to target patients and families who are at high risk, and to implement appropriate preventive and therapeutic strategies.

\section{7}

FAMILIAL ALZHEIMER'S DISEASE: STUDY OF A NEW ITALIAN KINDRED. L. Bergamini, * I. Rainero, L. Pinessi, G. Vaula; Dept. of Neurology, Univ. of Turin (Italy); A.C. Bruni, G. Gei, M.P. Montesi, C. Ermio; Dept. of Neurology, Lamezia Terme (Italy); and J.F. Foncin; Hop. La Salpétrière, Paris (France).

We have recently discovered in Torino (Italy) a new pedigree with Familial Alzheimer's disease. The index patient is a woman who became demented at age 43. Several relatives have had a history of dementia. The ancestors of the patient were from Calabria (Southern Italy) and members of the family emigrated to the North of Italy, to France and to the USA.

At present, the "Torino family" comprises 1085 members, distributed in 8 generations.24 members affected with Alzheimer's disease have been identified: 5 were diagnosed by personal examination, 12 by medical records and 7 by history. Mean age at death of the patients is $50.5 \pm 9.2 \mathrm{yr}$ (range 43-59). The pedigree is consistent with autosomal dominant inheritance.

The "Torino family" shows several similarities with the Family N, described by Foncin et al. (1): the ancestors were born in the same country of Calabria, neurological and psychiatric symptoms are the same in the two families and no difference in age at onset of the disease and age at death was found. We are tryirg to find a direct linkage between these two kindreds. Molecular genetic of this new family is currently under investigation.

1.Foncin JF et al. Rev.Neurol (Paris), 1.41:194202,1985 .

188

DIFFERENCES IN POSTURAL SWAY PATTERNS IN INDIVIDUALS WITH ALZHEIMER DISEASE WITH AND WITHOUT HISTORY OF FALLS: A PIIOt Study. A. Bhattacharya and C. Cox, Dept. of Environinental Health; S. Gilster, Alois Alzheimer Center; A. McCracken, College of Nursing; and $G$. Warshaw, Geriatric Division of the University of Cincinnati Medical School; Cincinnati, Ohio, U.S.A.

Persons with Alzheimer's Disease (AD) have more than three times the risk of falling than cognitively healthy elderly persons. Regardless of the physlological conditions for which falling is a marker, the most significant risk factor is the impairment of postural balance. In an effort to determine the ability to perform quantitative postural sway measurements in the subjects with $A D$ and differences in postural sway patterns in patients with and without history of falls, a pilot study with 2 male and 2 female patients was performed. Out of 4 pa. tients (mean age: 84.7 yrs.), 2 had previous history of falls. Postural sway testing was conducted on these patients with Haycox Rating Scale scores of 16 to 26. The postural balance or sway was noninvasively quantitated with a microprocessor-based force platform system. Each patient performed four tasks i.e., EO: Eyes open on force plate; EG: Eyes closed on force plate; FO: Eyes open on foam pad placed on the force plate; and FC: Eyes closed on foam pad placed on the force plate. This test allows quantification of the movement pattern of body's center of pressure associated with postural sway. These tests were designed to indirectly evaluate the roles of vision, proprioception and the vestibular system for postural balance. The patients with previous history of falls had difficulty in completing $F O$ and $F C$ tests. In particular, postural sway responses for the fallers were significantly larger than the nonfallers for the FO(up to 3.9 times) and $F C$ (up to 4.7 times) tests where the vestibular system is placed at a higher challenge compared to EO and EC tests. Furthermore, frequency of sway patterns in the fallers $(0.08 \mathrm{~Hz}$ for lateral sway and $0.11 \mathrm{~Hz}$ for anterior. posterior $[\mathrm{A}-\mathrm{P}]$ sway) were low compared to the nonfallers $(0.18 \mathrm{~Hz}$ for lateral sway and $0.23 \mathrm{~Hz}$ for A-P sway) which is consistent with vestibular-controlled postural balance characteristics. In summary, the result of our above-mentioned case study indicates that postural sway testing can be safely performed in the Alzheimer patients and there exists a significant difference in postural sway response between fallers and nonfallers.

\section{9}

APPUICATION OF RESEARCH CRITERIA FOA DEMENTIA IN COMMON CUNICAL PRACTICE *F. R.J Vemey, R.W.H.M. Ponds, E.J. Royerson van Buwren, F.W. Vreeling and J. Jolles, Departments of Neuropsychology and Poychotilology and Vreeling and J. Jolles, Departments of Neuropsychology and Peycholidogy and
*Neunology; Untversity of Limburg, P.O. Box 616, 6200 MD Madedicht, The Netherlands

Recently, dlagnostic criteria were proposed for the clinical and research diagnosis of dementia and Azhelmar's Disease (AD) wh the aim of reschtry higher degree of homogenely in pettent-groups (DSM-HIA and NiNCDS/AD FDA) The preent study addreseses the qubetion whether, and to whet extert, a dleonodic approach based upon the recommended procedures thads to an oticome which to approach based upon the recommended procedurea lacds to an oflcome which to

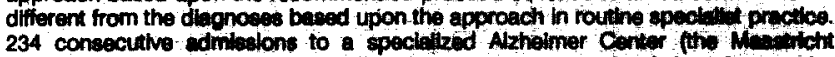
Memory Clinic MMC) were comparid to dlagnoses made prevloudy by rolemers who had not used such a model. Al patients (mean age 62.8 yeans) were referred because of a memory problem, whish could vary from mid sub fettwe complatws to included a eml-structured thtentew wh the patlem and hl hitomant, an oxtended neuropsychologicel testbettery, blocktests, and CT-scan. Furthemore, the following neuropsychologlcel testbattery, bloctrests, and CT-scan. Furthermore, the following

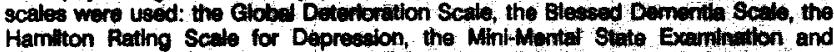

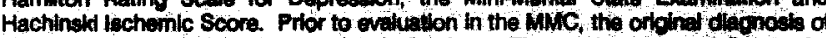
the referrer was obtained from an admibolon form. The rearth wore as thowe the diagnases was chanod in 66 out of 166 pationts. Out of 73 patlents, relerred as a dementita, the diagnods wes changed in 32 cases (44\%): in 12 caes, the crtterta for dementia were not met: In 6 cases the defict was foced end in 6 other cases the dementia were not met: in 6 cases the deficit was fockd and in 6 other cases the

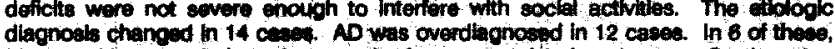
history taking reweeded cencbrovaccular factors, provlously unknown. On the other hand, the dlagnosts of dementia wes made in 34 (21\%) of 161 pattents, previoush not dlagnosed as such. These were all cases of mild demertia. Thls ofidy shows that the extensive approach as recommended for research leads to substantial 
changes in diagnostic outcome, compared to procedures in daily practice. Most of the discrepancies pertain to the evaluation of the clinical condition. This underlines the importance of a thorough, albeit time consuming, clinical evaluation, which cannot be replaced by laboratory and $X$-ray data. The diagnosis of dementia and dementing diseases should be based on an integrated mult-disciplinary and systematic model, with explicit definitions of terms and taking into account all in- and exclusion crtteria.

\section{BRAIN AMYLOIDOSIS}

\section{0}

PATHOGENESIS OF BETA-AMYLOID FIBER FORMATION. *H.M. Wisniewski, J. Wegiel, A.W. Vorbrodt, M. Wrzolek, J.R. Currie, NYS Institute for Basic Research in Developmental Disabilities, Staten Island, NY 10314 (USA)

Amyloid deposition in the brain accompanies normal aging and $A D$ as well as unconventional viral disease and Down's syndrome. In each case, the amyloid deposits exhibit generally similar morphologies but with differences characteristic for each condition. In all of the above mentioned conditions, the presence of amyloid fiber deposits appears to be limited to the CNS. However, by means of in situ hybridization and immunohistochemical methods, it has been shown that many cell types within and outside the CNS could be the source of the beta-protein in Alzheimer disease (AD). Ultrastructural studies strongly indicate that the resident macrophage population of cells in the brain, the microglia, are the cells producing the beta-amyloid fibers. These cells, which contain a labyrinth of amyloid-filled channels, show a clear polarity in relation to the amyloid deposits. The amyloid fibers appear to form in altered cisterns of endoplasmic reticulum, and there is some indication that the beta-protein may bypass the Golgi complex. Because the amyloid fibers are first seen in the distended cisterns of the smooth endoplasmic reticulum system, it appears that these cells are engaged in the formation, not the phagocytosis, of the amyloid fibers. The configuration of extracellular bundles of amyloid fibrils radiating from indentations in the cytoplasm of Kupffer and reticular cells of the liver and spleen in systemic amyloidosis has been found to be identical in many details with amyloid star formation by microglial cells in $A D$ brain. We hypothesize that the microglia/ macrophages (which are probably both the producer and processor cells) synthesize and secrete the betapeptide either as an overexpressed, truncated gene product or as an aberrant peptide resulting from abnormal post-translational processing.

191

\section{AMYLOID BA4 PROTEIN PATHOLOGY IS CENTRAL TO THE CAUSE OF} ALZHEIMER'S DISEASE

'K. Beyreuther, W. Schubert, G. Multhaup, J.M. Salbaum, J. Beer, C. Hilbich, G. Konig, T. Dyrks, A. Weidemann, P. Fischer, D. Bunke, U. Monning, N. Catteruccia, H. Mechler, R. Prior, T. Kitamoto, E. Schlichtmann, E. Mack-Kühn, C.L. Masters * ZMBH, Center for Molecular Biology, University of Heidelberg, F.R.G.

*Department of Pathology, University of Melbourne, Parkville, Victoria 3052 Australia

On the molecular level Alzheimer's disease $(A D)$ is characterized by amyloid BA4 protein, which accumulates primarily in the hippocampus and neocortex. The massive deposition of fibrillar BA4 protein aggregates found in AD brain is reminiscent of storage diseases. The preclinical period of amyloid BA4 protein accumulation was estimated by us to approximate 30 years.

Since the same molecular neuropathological changes are observed in trisomy 21 Down's syndrome, the AD amyloid BA4 pathology is suggested to be due to abnormal expression of genes located on human chromosome 21.

The demonstration of the gene (PAD/APP) encoding the amyloid precursor protein (Pre A4) to map to chromosome 21 strongly suppons our hypothesis that this gene and its pathological product is central to the causation of $A D$.

The exon structure of the PAD gene revealed that amyloid BA4 protein can not be produced by alternative splicing and therefore has to be generated by abnormal pathological degradation of transmembrane Pre A4 proteins which in contrast to secretory Pre A4 proteins include the BA4 sequence as part of the ecto- and transmembrane domains.

Since the amyloidogenic transmembrane Pre A4 proteins are abundantly expressed in neurons, anteriogradely transported in axons and located at synapses, the pathological degradation to BA4 protein has to occur either in neurons or between synapses.

Thus, chronic extra- and intracellular amyloid BA4 protein formation in brain would occur at sites relevant for impairmem of imellectual functions, gradually reduce the synaptic density and finally result in the clinical features of $A D$.

\section{2}

AMYLOID B-PROTEIN DEPOSITION AS A SEMINAL PATHOGENETIC EVENT IN AD: AN HYPOTHESIS $\star$ D, J. Selkoe. Harvard Medical School and Brigham and Women's Hospital, Boston, MA 02115.

Evidence emerging from numerous laboratories during the last two years suggests that amorphous, largely non-fibrillar deposits of the amyloid $B$-protein (ABP) precede the development of neuritic plaques, neurofibrillary tangles, gliosis and other cytological changes in Alzheimer's disease (AD) and Down's syndrome (DS). We studied such diffuse plaques to advantage in $\mathrm{AD}$ cerebellum and strlatum, where they are virtually the only form of $A B P$ deposit found even at the end of the disease (Joachim et al., Am. J. Path. $135: 309,1989$ and J. Neuropath. Exp. Neuro1. $87: 330,1 \overline{989})$. If local neuronal/neuritic alteration were a prerequisite for $A B P$ deposition, one would expect some morphological evidence of neuritic abnormality after years of cerebellar and striatal ABP deposition, particularly since profound neuritic pathology surrounds many $A B P$ deposits in cerebral cortex. Similarly, sizable numbers of diffuse $A B P$ deposits can be found in some 25-35 year old DS subjects at a time when no neuritic or glial abnormality is detectable. Recently, we discovered $A B P$-immunoreactive deposits in vessels and/or perivascular tissue of skin and other non-neural tissues in AD and DS, suggesting that ABP deposition can occur in the absence of neuronal or gltal injury, indeed, in the absence of neurons and glia. These and other observations all strongly suggest that $\beta$-amyloidosis in $A D$, like other better characterized amylodioses, is not secondary to local cellular change but precedes it. We, therefore, hypothesize that in normal aging, an alternate, minor pathway for APP proteolytic processing exists that results in release of amyloidogenic fragments of APP containing the intact $A B P$ region. In DS, this alternate pathway, which is normally used at a low level, is overutilized due to the increased expression of APP molecules that results from higher gene dosage. In FAD, rearrangements or mutations on ch. 21 (in at least some families) lead to a dysregulation of APP biosynthesis that results in more APP molecules being processed through the minor pathway and increased genesis of ABP, producing a histologic phenotype that is indistinguishable from that of DS. The progressive deposition of $A B P$ in $D S$ and $F A D$ initiates. efther directly or indirectly, a cascade of secondary cellular changes (including local neurite growth) that, over years or decades, produce neuronal dysfunction and thus dementia.

\section{3}

ROLE OF IMMUNE FACTORS IN AMYLOIDOGENESIS IN ALZHEIMER BRAIN T. Ishii, S. Haga, M. Satoh, and F. Kametani, Psychiatric Research Institute of Tokyo, Setagaya-Ku, Tokyo 156, Japan.

The earliest stage of deposition of amyloid protein and fibril formation (amyloidogenesis) in the Alzheimer brain was studied by immunohistochemical methods using antibodies to subsequences of amyloid precursor protein (APP), immunoglobulins (IG), complements (CP), $\alpha 1$-antichymotrypsin (ACT) and microglia.

IG, CP C1q, C4, C3 and ACT are present in "diffuse plaques" which are thought to be the earliest stage of amyloid deposition. In addition, the monoclonal antibody to senile plaques which was reported previously (Ishii et al., Neuropathol \& Appl Neurobiol 12 , 1986) proved to react with epitopes in the light chain of IGS, thus indicating the presence of the latter epitopes in close association with the amyloid fibrils in the Alzheimer brain. In the case of complement immunohistochemistry, immuno-EM pictures revealed the deposition of a homogeneous material (probably preamyloid substance) near the immunoreactive amyloid fibrils, indicating the possible role of CP fixation in fibril formation. Microglial cells are few in number in the area of diffuse plaques but later the numbers increase and microglia accumulate in and around mature plaques. The above immunological factors are thought to be secreted by activation of macrophages through interleukin 1 and the process may be interpreted as a kind of chronic inflammation. The problem is what kind of antigen or antigens stimulate such an inmunological response in the process of amyloid deposition in the Alzheimer brain.

Aberrant catabolism of APP with membrane damage is proposed as the cause of amyloid formation. Certainly trophic as well as toxic effects of $\beta$-protein are reported. However, abnormal breakdown products of physiological substances usually lead to 